Дашадондокова Арюна Гармаевна

аспирант кафедры социальных технологий Восточно-Сибирского государственного университета технологий и управления

\section{ГОСУДАРСТВЕННАЯ ПОЛИТИКА РОССИЙСКОЙ ФЕДЕРАЦИИ В СФЕРЕ МИГРАЦИИ: НОРМАТИВНО- ПРАВОВАЯ ОСНОВА (НА ПРИМЕРЕ РЕСПУБЛИКИ БУРЯТИЯ)}

\section{Аннотация}

В статье представлены вопросы регулирования миграционных процессов (МП) в Российской Федерации Автором рассмотрены современная законодательная база, ее проблемы и механизм реализации в Республике Бурятия. Сделан анализ развития миграционной политики в постсоветский период, в результате чего автор пришел к выводу, что органы государственной власти в области МП принимали сложные, противоречивые, иногда непоследовательные меры в сфере управления миграционными процессами. Отмечается двойственность положения органа государственной власти в регионе: $c$ одной стороны, главная цель - привлекать иностранных граждан, декларируемая в законодательных акmax, a c другой - федеральное правительство имеет стабильный курс на уменьшение потока ми грантов с низкой квалификацией труда. В Республике Бурятия значительно возросла численность предприятий и учреждений (в том числе коммерческих), применяющих рабочую силу иностранных граждан. Возникает потребность в регулировании этого процесса на основе республиканских норма тивно-правовых актов. Однако МП региона развивается как неполноценная система, так как постоянно сталкивается с жесткими ограничениями со стороны федеральных органов власти. По мнению автора, эфффективная государственная миграционная политика должна учитывать особенности региона, что в свою очередь приведет к социально-экономи ческому, демографическому росту, обеспечит наци ональную безопасность не только страны в целом, но и каждого региона России.

Ключевые слова:

миграция, мигрант, миграционный процесс, миграционная политика, Республика Бурятия, законодательство, право, государство.
Dashadondokova Aryuna Garmaevna

PhD student, Social Technologies Department, East Siberia State University of Technology and Management

\section{THE STATE MIGRATION POLICY OF THE RUSSIAN FEDERATION: LAWS AND REGULATIONS (BY A CASE STUDY OF THE REPUBLIC OF BURYATIA)}

\begin{abstract}
Summary
The paper deals with the regulation of migration processes in the Russian Federation. The research reviews the modern legislation, its challenges and implementation mechanism in the Republic of Buryatia. Analyzing the migration policy development in the post-Soviet period, the author concluded that migration public authorities took complex, contradictory, and inconsistent measures to manage migration processes. Nowadays, state authority activities are of dual nature. On the one hand, its main goal to attract foreign nationals is declared in the legislative instruments. On the other hand, federal government stays on the stable course to reduce the flow of low-skilled migrants. The number of enterprises and institutions (including commercial ones) employing foreign nationals has considerably increased in the Republic of Buryatia. There is a need for regulation of this process based on regional laws and regulations. However, the migration process in the region is developed as an incomplete system, as it faces the severe restrictions imposed by the federal authorities on the daily basis. In the author's opinion, an effective state migration policy should take into account the peculiarities of the region. This, in turn, will lead to the social, economic, and demographic growth and ensure the national security of Russia in general and each region in particular.
\end{abstract}

Keywords:

migration, migrant, migration process, migration policy, Republic of Buryatia, legislation, law, state.

Понятие «миграционная политика» (далее - МП) уже несколько десятилетий является одной из самых дискутируемых проблем современности. Ее решение образует комплекс организационных, иституциональных, нормативно-правовых, финансово-экономических и иных мер, осуществляемых государственными и муниципальными органами власти, политическими партиями и т. д. [1, р. 438].

Рассмотрение нормативно-правовых основ МП невозможно вне анализа его исторической сущности. Рассмотрим постсоветский период, так как распад СССР привел к новым внешним миграционным процессам в странах бывших социалистических республик. С начала 1990-х гг. именно из Центральной Азии наблюдался мощный поток вынужденных мигрантов в Россию. В дальнейшем стали расти масштабы легальной и нелегальной трудовой миграции населения, что повлияло на разработку новых законодательных актов для решения возникающих проблем в связи с увеличением миграционного потока в Россию. В развитии МП Российской Федерации в постсоветский период (таблица 1) выделяются семь этапов [2, с. 50]. 
Таблица 1 - Этапы развития миграционной политики Российской Федерации

\begin{tabular}{|l|l|}
\hline \multicolumn{1}{|c|}{ Период } & \multicolumn{1}{c|}{ Направление } \\
\hline $1991-1994$ & приоритетное управление вынужденными мигрантами \\
\hline $1994-2000$ & расширение целей МП \\
\hline $2000-2002$ & преобразование и застой МП \\
\hline $2002-2006$ & усиление МП \\
\hline $2006-2009$ & $\begin{array}{l}\text { изменение порядка регистрации и трудоустройства иностранных граждан, поощре- } \\
\text { ние переселения проживающих за рубежом соотечественников }\end{array}$ \\
\hline $2010-2014$ & $\begin{array}{l}\text { отбор приемлемых кандидатов для восполнения рабочих ресурсов (введение па- } \\
\text { тентов и разрешений на привлечение высококвалифицированных специалистов) }\end{array}$ \\
\hline $\begin{array}{l}2015-\text { настоящее } \\
\text { время }\end{array}$ & $\begin{array}{l}\text { исключение асимметричного механизма трудоустройства мигрантов из стран с без- } \\
\text { визовым режимом въезда (патент становится единым разрешительным докумен- } \\
\text { том на работу данной категории мигрантов) }\end{array}$ \\
\hline
\end{tabular}

При анализе этапов автор пришел к выводу о том, что органы государственной власти в области МП принимали сложные, противоречивые, иногда непоследовательные меры в сфере управления миграционными процессами. В то же время объективная оценка результативности МП России может быть дана только на основе единой онтологической (исторической) систематизации.

Систематизация законодательного обеспечения государственной МП по фракту сформировалась в 2003 г., в связи с принятием федерального закона «О правовом положении иностранных граждан в Российской Федерации» и внесением дополнений в федеральный закон «О занятости населения в Российской Федерации». Также в 2003 г. созданы и действуют Правительственная комиссия по миграционной политике и межведомственная рабочая группа по подготовке предложений по совершенствованию миграционного законодательства Российской Федерации.

Однако невозможно создать единый миграционный закон, распространяющийся на внешнюю и внутреннюю миграцию и поглощающий нормы остальных отраслей права, имеющих отношение к регулированию этих процессов. Также не исключается фракт создания федерального закона, определяющего основные положения миграции. Возникает необходимость проведения дифференциации компетенций между органами власти на федеральном и региональном уровнях РФ в сфере регулирования миграции. Также необходимо сформировать региональную правовую базу для регулирования миграционных процессов, при этом учитывая, что некоторые полномочия сореры миграции сосредоточиваются только у федеральных органов власти.

Развитие и формирование МП в субъектах РФ имеет на сегодняшний день немаловажное значение. Исследование ее правовых границ, сложившихся практик, работы институтов на субъектном уровне - эти задачи имеют чрезвычайную важность и актуальность, с одной стороны, а с другой - почти не изучены.

Миграционная политика Республики Бурятия (далее - РБ) с начала 90-х гг. XX в. характеризовалась отсутствием значительных норм права в сфере регулирования миграции, но в 2000-х гг. переходит к «властной вертикали», которая устанавливала для субъекта подотчетность федеральному центру в целях повышения эффективности регулирования миграции. Из-за стабильного сокращения численности населения, низкого уровня миграции в условиях подъема экономической ситуации, субъекты (в частности, к востоку от Урала) в 2000-е гг. встретились с потребностью разработки специфичных, региональных программ и механизмов регулирования миграции, приняв во внимание их особенности и потребности. Впрочем, задачи субъектных органов государственной власти были ограничены до целей реализации установок государственной МП Российской Федерации.

Проанализировав нормативные документы Республики Бурятия и ее муниципалитетов, автор пришел к выводу, что большая часть охватывает только внешнюю миграцию. Ресурсы регионов России носят ограниченный характер, с одной стороны, их полномочия координировать потоки иммигрантов и эмигрантов находятся во власти только федерального законодательства, а с другой стороны, у регионов разное географическое положение, и фрактически именно приграничные и соседние республики и области напрямую имеют дело с трансграничной миграцией. Происходит столкновение интересов республики и находящихся на его территории муниципальных образований с интересами федерального ведомства. Внутренняя миграция (как региональная, так и межрегиональная), имеющая большое значение для большинства субъектов РФ, при таком методе остается чаще всего вне зоны деятельности органов власти региона.

Республика Бурятия находится между Уралом и Дальним Востоком, что определяет особенности межрегиональных процессов миграции на ее территории. Кроме того, республика имеет общую границу с Китайской Народной Республикой и Монголией, связывая РФ и Центральную Азию. Это во многом определяет геополитическую ценность Бурятии, поскольку она занимает центральное место в Евразии. Таким образом, направление развития и расположение России как уникального евразийского государства в большинстве своем обусловливается перспективами роста Байкальского региона. 
Современные региональные исследователи отмечают в качестве особенностей Бурятии многоуровневый характер идентичности местного населения республики и ее влияние на успешность адаптации мигрантов на данной территории [3, с. 258].

Автором проведен анализ МП Республики Бурятия, в первую очередь это касается Постановления от 17 мая 1993 г. № 103 «О порядке использования труда иностранных граждан на территории Республики Бурятия». Экономические рефрормы, реализующиеся в РБ, обеспечивают развитие межнациональных связей в республике, что в свою очередь способствует значительному возрастанию численности предприятий и учреждений (в том числе коммерческих), применяющих рабочую силу иностранных граждан и специалистов на договорной основе. Возникает потребность в регулировании этого процесса на основе республиканских нормативно-правовых актов.

В 1992-1995 гг. органы управления миграционными процессами республики четко контролировали все требования совета министров РБ, которые предъявлялись к руководству предприятий, организаций и учреждений в использовании результатов деятельности иностранных граждан. Тем не менее фиксировались задержка сроков или отказы предприятий и учреждений в выдаче лицензий, выявлялись случаи использования недействительных рабочих договоров или соглашений, расторжения рабочих контрактов в одностороннем порядке, игнорировались требования о медицинском и санитарном обследовании иностранных граждан.

Народный хурал 25 января 1995 г. принял закон Республики Бурятия «О порядке пребывания иностранных граждан и лиц без гражданства на территории Республики Бурятия». Закон устанавливал порядок пребывания на территории РБ иностранных граждан и лиц без гражданства, а также иностранных граждан и лиц без гражданства, приехавших в РБ из других регионов РФ; порядок проездного транзита через территорию РБ и в первую очередь был направлен на охрану интересов населения РБ.

Привлекать иностранных граждан к трудовой деятельности на территории республики имели возможность предприятия, учреждения и организации, а также граждане субъекта при оформлении специального разрешения, предоставленного Управлением федеральной миграционной службы.

Цели миграционного учета в РБ: 1) создать необходимые условия для осуществления своих возможностей и прав иностранными гражданами и гражданами РФ; 2) вырабатывать и реализовывать государственную миграционную политику; 3) формировать полную, достоверную, оперативную и актуальную инфрормацию о перемещениях мигрантов, которая необходима для прогноза результатов указанных перемещений, а также для обеспечения национальной безопасности РФ.

Из этого вытекает двойственность положения органа государственной власти в регионе. С одной стороны, главная цель - привлекать иностранных граждан, декларирующаяся в законодательных актах и обращениях к населению. А с другой стороны, федеральное правительство имеет стабильный курс на уменьшение потока мигрантов с низкой квалификацией труда. Для РБ, привлекающей в основном иностранных граждан в такие сферы, как строительство, дорожное строительство, сельское хозяйство, обслуживание, торговлю, не имеет большого значения высокая квалификация иностранных граждан, так как на территории республики не много производств, требующих высококвалифицированных специалистов. По сути, миграционная политика как таковая именно в РБ отсутствует, а в субъектах РФ осуществляются только цели МП России в целом, с характерными для нее четко очерченными границами деятельности и дружелюбной риторикой. Как видно, имеющаяся проблема не находит отклика у федеральных органов власти, и простое решение напрашивается само - следовать общегосударственному курсу МП, не учитывая потребности субъекта РФ.

Современное государственное положение миграционных процессов в РФ носит следующие черты: 1) РФ приступает к созданию многосторонней, общенаучной систематизации при регулировании миграции на территории России, взяв за основу Концепцию государственной миграционной политики РФ до 2025 г.; 2) на современном этапе при регулировании миграционных процессов фе-деральные органы начали разделять компетенции с региональными органами власти; 3) необходимо совершенствовать государственное регулирование в сфере миграции с учетом законодательного, институционального, фринансового, информационного, научного и кадрового обеспечения.

Таким образом, возникает необходимость учета особенностей Республики Бурятия, так как удовлетворение объективных потребностей в увеличении или уменьшении количества иностранных граждан в регионе сильно затрудняется действиями федеральных органов власти. Имеются серьезные противоречия между интересами федеральной и региональной власти, проявляющиеся в методах ведения бизнеса внутри региона. На наш взгляд, легитимный выход их противоречий на данном этапе развития миграционного законодательства не удается. Поэтому МП региона развивается как неполноценная система, постоянно сталкиваясь с жесткими ограничениями со стороны федеральных органов власти. Эффективная государственная миграционная политика должна учитывать особенности региона, что в свою очередь приведет к социально-экономическому, демографрическому росту, обеспечит национальную безопасность не только страны в целом, но и каждого региона России. 


\section{Ссылки:}

1. Ueffing P., Rowe F., Mulder C.H. Differences in attitudes towards immigration between Australia and Germany: The role of immigration policy // Comparative Population Studies. 2015. Vol. 40, no. 4. P. 437-465.

2. Кочеткова Н.Д. Правовое регулирование миграционной политики Российской Федерации // Научный вестник Орловского юридического института МВД России им. В.В. Лукьянова. 2015. № 1. С. 50-52.

3. Антонов В.И., Очирова О.А. Российская идентичность как фактор национальной безопасности в фокусе современных миграционных процессов: региональные особенности и противоречия // Обеспечение национальной безопасности России в современном мире : материалы международной научно-практической конференции. Иркутск, 2016. C. 253-260.

\section{References:}

Antonov, VI \& Ochirova, OA 2016, 'Russian identity as a factor of national security in the focus of modern migration processes: regional characteristics and contradictions', Obespecheniye natsional'noy bezopasnosti Rossii v sovremennom mire: materialy mezhdunarodnoy nauchno-prakticheskoy konferentsii, Irkutsk, pp. 253-260, (in Russian).

Kochetkova, ND 2015, 'Legal regulation of the migration policy of the Russian Federation', Nauchnyy vestnik Orlovskogo yuridicheskogo instituta MVD Rossii im. V.V. Luk'yanova, No. 1, pp. 50-52, (in Russian).

Ueffing, P, Rowe, F \& Mulder, CH 2015, 'Differences in attitudes towards immigration between Australia and Germany: The role of immigration policy', Comparative Population Studies, vol. 40, No. 4, pp. 437-465. 